\title{
Dairy processing and cold storage affect the milk coagulation properties in relation to cheese production
}

\author{
Guilherme de Moura Maciel • Marianne Hammershøj • \\ Pernille Dorthea Frederiksen • John Sørensen • \\ Mette Bakman • Nina Aagaard Poulsen • Lotte Bach Larsen
}

Received: 31 May 2014 /Revised: 17 September 2014 / Accepted: 20 October 2014 /

Published online: 14 November 2014

(C) INRA and Springer-Verlag France 2014

\begin{abstract}
The development of coagulation properties during cold storage of raw milks categorized as good or poorly coagulating is largely unknown. This was studied in the present investigation at individual cow's milk level in addition to elucidating the impact of cheesemaking processing steps on the resulting coagulation properties of silo tank cheesemilk. Rennet coagulation time (RCT), curd firming rate (CFR) and gel firmness (G'max); $\mathrm{Ca}, \mathrm{P}$ and $\mathrm{Mg}$ distribution; $\mathrm{pH}$; and casein micelle size of raw skim milk from individual cows classified as "good" or "poor" in coagulation properties were investigated over $72 \mathrm{~h}$ storage at $4{ }^{\circ} \mathrm{C}$. For the cheesemilk, the impact of overnight cold storage, thermization and standardization, pasteurization, and acidification to either $\mathrm{pH}$ 6.45 or 6.30 on the coagulation properties were studied. After $24 \mathrm{~h}$ of cold storage, RCT of both good and poorly coagulating milks was significantly prolonged though recovering somewhat after prolonged storage for good coagulating samples. In contrast, G'max was significantly reduced after $72 \mathrm{~h}$ of cold storage for good coagulating milk. Both total and colloidal Ca were higher in good compared with poorly coagulating milk, while mineral distribution and milk $\mathrm{pH}$ did not change during storage. For cheesemilk, up to $14 \mathrm{~h}$, cold storage did not impair coagulation properties significantly, which was markedly improved by acidification. The study shows that rheological parameters of good and poorly coagulating milks are impacted differently by the cold storage. Conversely, cheesemilk coagulation properties were not impaired by the studied cheesemaking processing steps and, further, were enhanced by acidification steps.
\end{abstract}

This paper is part of the special issue dedicated to the 2nd International Symposium on Minerals \& Dairy Products (MADP2014) held on 26-28th February 2014 in Auckland, New Zealand.

G. M. Maciel • M. Hammershøj • N. A. Poulsen • L. B. Larsen $(\bowtie)$

Department of Food Science, Aarhus University, Blichers Allé 20, 8830 Tjele, Denmark

e-mail: lottebach.larsen@agrsci.dk

P. D. Frederiksen

Arla Foods Ingredients, Sønderhøj 14, 8260 Viby J, Denmark

J. Sørensen · M. Bakman

Arla Strategic Innovation Centre, Rørdrumvej 2, 8220 Brabrand, Denmark 
Keywords Milk $\cdot$ Cheese $\cdot$ Coagulation $\cdot$ Chymosin $\cdot$ Storage $\cdot$ Processing

\section{Introduction}

Cheesemaking properties of milk are of importance not only for cheese quality and yield but also for the process control at the dairy. Many factors influence the suitability of cow's milk for further use in rennet- or chymosin-induced coagulation process. This includes the quality and composition of the raw milk, as well as conditions relating to the further handling and processing of the milk, including cooling and pasteurization. Regarding the raw milk quality, it has been well documented that unprocessed milk from individual cows represents a wide range of qualities for chymosin-induced coagulation properties (Jõudu et al. 2008; Hallén et al. 2010; Frederiksen et al. 2011b).

It is clear that the majority of samples present not only good coagulation properties but also poor coagulating and even non-coagulating milk (Ikonen et al. 2004; Frederiksen et al. 2011a; Poulsen et al. 2013). The reasons behind this variability can be many, as a variety of factors influence the milk coagulation properties, including lactation stage, somatic cell count, breed, and parity, and these factors influence the properties by manifestation of changes in the milk composition (Devold et al. 2000; Ikonen et al. 2004; Frederiksen et al. 2011b).

Commonly identified risk factors for poor coagulating and non-coagulating milk include low casein $(\mathrm{CN})$ content, especially low $\mathrm{K}-\mathrm{CN}$ content, $\mathrm{K}-\mathrm{CN}$ genetic polymorphism, larger $\mathrm{CN}$ micelles, and lower $\mathrm{Ca}$ content (Tsioulpas et al. 2007; Frederiksen et al. 2011a; Jensen et al. 2012; Gustavsson et al. 2014; Malacarne et al. 2014), but the underlying reasons are still not completely elucidated. Indeed, there is no report in the literature on how milks with distinct coagulation abilities respond to cold storage.

Chymosin-induced coagulation is a two-stage process. The first stage consists of the cleavage of $\mathrm{K}-\mathrm{CN}$ by chymosin into para- $\mathrm{K}-\mathrm{CN}$ and caseinomacropeptide (CMP). When approximately $85 \%$ of the $\mathrm{K}-\mathrm{CN}$ has been cleaved, the formation of aggregates is initiated. An increase in viscosity is observed followed by branching of the aggregates, thus characterizing the second stage (Dalgleish and Corredig 2012). It has been questioned whether $\mathrm{k}-\mathrm{CN}$ molecules in poor and non-coagulating milks are actually cleaved to the same extent as $\mathrm{K}-\mathrm{CN}$ in good coagulating milk by chymosin, but in an earlier study, it was observed that the first phase occurred to comparable extent in both good and non-coagulating milk (Frederiksen et al. 2011a).

Impaired coagulation properties of milk samples from individual cows thus seem to be related to the second phase of gelation and to the risk factors mentioned above. For assessing the chymosin-induced coagulation properties of milk, a free oscillatory rheometry method has been described (Frederiksen et al. 2011b). In this method, the coagulation parameters including rennet coagulation time (RCT), curd firming rate (CFR), and curd firmness (G'max) can be deduced, all representing parameters relating to the second phase of coagulation. Therefore, the method is suitable for characterizing variability in coagulation properties of cheesemilk as well as how these properties are affected by processing steps at a cheese dairy level.

Technological interventions in the milk through the cheese production line (i.e., cold storage, fat standardization, pasteurization, $\mathrm{CaCl}_{2}$ addition, and acidification) may have 
a substantial impact on milk's physicochemical characteristics and, consequently, on its rheological properties and the cheese characteristics (De la Fuente 1998; Lucey 2002).

It is known that $\mathrm{pH}$ affects the rate of renneting, curd firmness, and syneresis, as well as fat recovery, Ca retention, and, consequently, the final texture of cheese (Watkinson et al. 2001). Furthermore, it has been demonstrated that milk acidification reduces the RCT, whereas G'max is inversely related to the $\mathrm{pH}$ (Mellema 2002; Tsioulpas et al. 2007). By acidifying milk (e.g., bacterial fermentation, addition of acid, and $\mathrm{CO}_{2}$ ), rennet activity is increased, as the optimum $\mathrm{pH}$ of chymosin is $\mathrm{pH} \sim 6.0-6.3$ (Crabbe 2004), and micelle aggregation is induced at a lower degree of $\mathrm{k}-\mathrm{CN}$ hydrolysis due to a reduction of the electrostatic repulsion (Lucey 2002). Milk acidification also dissolves colloidal $\mathrm{Ca}$ phosphate and increases the $\mathrm{Ca}^{2+}$ activity, which reduces the repulsion between the negatively charged caseins and participate in specific ion-bindings taking place in the second stage of rennet-induced coagulation (Dalgleish and Corredig 2012; Malacarne et al. 2014).

Moreover, milk is stored cold in periods of various lengths before cheesemaking. Cold storage of milk promotes a small dissolution of the colloidal $\mathrm{Ca}$ phosphate and $\beta-\mathrm{CN}$, which is claimed to impair milk rennet coagulation, by increasing RCT and reducing curd firmness, hence lowering the cheese yield (Ali et al. 1980; Raynal and Remeuf 2000). However, pasteurization of cold stored milk is known to recover its coagulation properties to some extent by reversing the abovementioned changes in the casein micelle structure (De la Fuente 1998; Gaucheron 2005).

Indeed, Jensen et al. (2012) associated better coagulation abilities from milk samples collected from individual Jersey and Holstein cows to higher contents of colloidal Ca, $\mathrm{P}$, and $\mathrm{Mg}$. Even though mineral composition of the casein micelles has an impact on milk coagulation and cheese processing, it does not seem to influence CN micelle size (Dalgleish et al. 1989; Devold et al. 2000). Several studies have reported that rennetinduced coagulation of milk samples containing smaller casein micelles presented good coagulation properties (i.e., faster formation of aggregates and firmer curds), which can be related to differences in individual $\mathrm{CN}$ content, especially to the negative correlation between K-CN content and casein micelle size (Jõudu et al. 2008; Glantz et al. 2010; Frederiksen et al. 2011b).

Conversely, even milks with the same amount of CN can present significant differences in coagulation properties. Studies have associated the $\mathrm{K}-\mathrm{CN}$ variant AA genotype to larger CN micelles and impaired coagulation properties (Walsh et al. 1998; Frederiksen et al. 2011a; Jensen et al. 2012). Although genetic factors and feeding regimes influence milk coagulation ability to some extent, it is equally important to understand how the combination of the abovementioned factors can impact the gel formation and rheological characteristics of curds produced from milks with different coagulation abilities.

The aim of the present work was to study the effect of cold storage $(0,24$, 48 , and $72 \mathrm{~h}$ ) of milks classified as "good" or "poor" in coagulation properties on the development of coagulation properties, mineral distribution, and $\mathrm{CN}$ micelle size. In addition, we aimed to study the impact of various processing steps at a cheese dairy plant, including thermization and standardization, pasteurization, and acidification to $\mathrm{pH} 6.45$ and 6.30 on the same coagulation properties as for the individual milk samples. 


\section{Materials and methods}

\subsection{Cold storage of milk samples from individual cows}

Milk samples were collected from Danish Holstein cows' resident at the same herd at the Danish Cattle Research Center (Tjele, Denmark). Information about the animals, farming management, milking system, and overall milk composition were provided in a previous publication (Frederiksen et al. 2011b). In that study, individual morning milk samples from 20 healthy cows, without mastitis history, were collected and analyzed for chymosin-induced coagulation properties for six to ten times over a period of 7 months. The referred cows were classified as producers of good or poor coagulating milk (Frederiksen et al. 2011a). In the current study, milk samples were collected once in the morning from four of these cows classified as producing consistently good coagulating milk with short RCT, high CFR, and high G'max, and four cows classified as producing consistently poor coagulating milk with long RCT, low CFR, and low G'max were included.

These eight milk samples were skimmed by centrifugation twice at $200 \times \mathrm{g}$ for $20 \mathrm{~min}$ at $4{ }^{\circ} \mathrm{C}$. One hundred fifty milliliters of the skim milk was stored at $4{ }^{\circ} \mathrm{C}$ and analyzed for coagulation properties and mineral distribution at four storage periods $(0$, 24,48 , and $72 \mathrm{~h}$ ) and at two storage periods ( 0 and $72 \mathrm{~h}$ ) for casein micelle distribution.

\subsection{Processing of cheesemilk}

One batch of bovine milk of $\sim 15,000 \mathrm{~L}$ was collected at a range of dairy herds within $24 \mathrm{~h}$ of milking and processed for yellow cheese production at the dairy (Arla Foods amba, Brabrand, Denmark), as illustrated in Fig. 1. During the processing, a total of six sampling points were selected in which milk samples of $1 \mathrm{~L}$ were collected and analyzed in order to evaluate the impact of each processing step on cheesemilk coagulation properties.

\subsection{Coagulation properties}

Coagulation properties were measured by continuous measurement during rennet coagulation using a ReoRox4 oscillatory rheometer (MediRox AB, Nykoping, Sweden) as described previously (Frederiksen et al. 2011b). All skim milk samples from individual cows were adjusted to $\mathrm{pH} 6.5$ by addition of $10 \%(\mathrm{v} / \mathrm{v})$ lactic acid before analysis in order to remove the effect of varying $\mathrm{pH}$ on the coagulation properties. The $\mathrm{pH}$ of the milk samples was recorded both before and after $\mathrm{pH}$ adjustment.

For the cheesemilk samples, rheological measurements were realized in standardized $3.5 \%$ milk from the processing step 2 (Fig. 1). The assay was performed at unadjusted $\mathrm{pH}(6.62 \pm 0.04)$ for the processing steps $1,2,3$, and 4 and at $\mathrm{pH} 6.45$ and 6.30 for the processing steps 5 and 6 , respectively. The adjustment of $\mathrm{pH}$ in the cheesemilk was done by $\mathrm{CO}_{2}$ injection in the cheese tank after the addition of $8 \mathrm{~g} \mathrm{CaCl}_{2}$ solution $(34 \%$ $w / w)$ per $100 \mathrm{~kg}$ milk, as illustrated in Fig. 1.

At the laboratory, all milk samples were pre-incubated at $33^{\circ} \mathrm{C}$ for $30 \mathrm{~min}$ before the addition of 0.038 international milk clotting units (IMCU) per milliliter milk of ChyMax 
Day 1
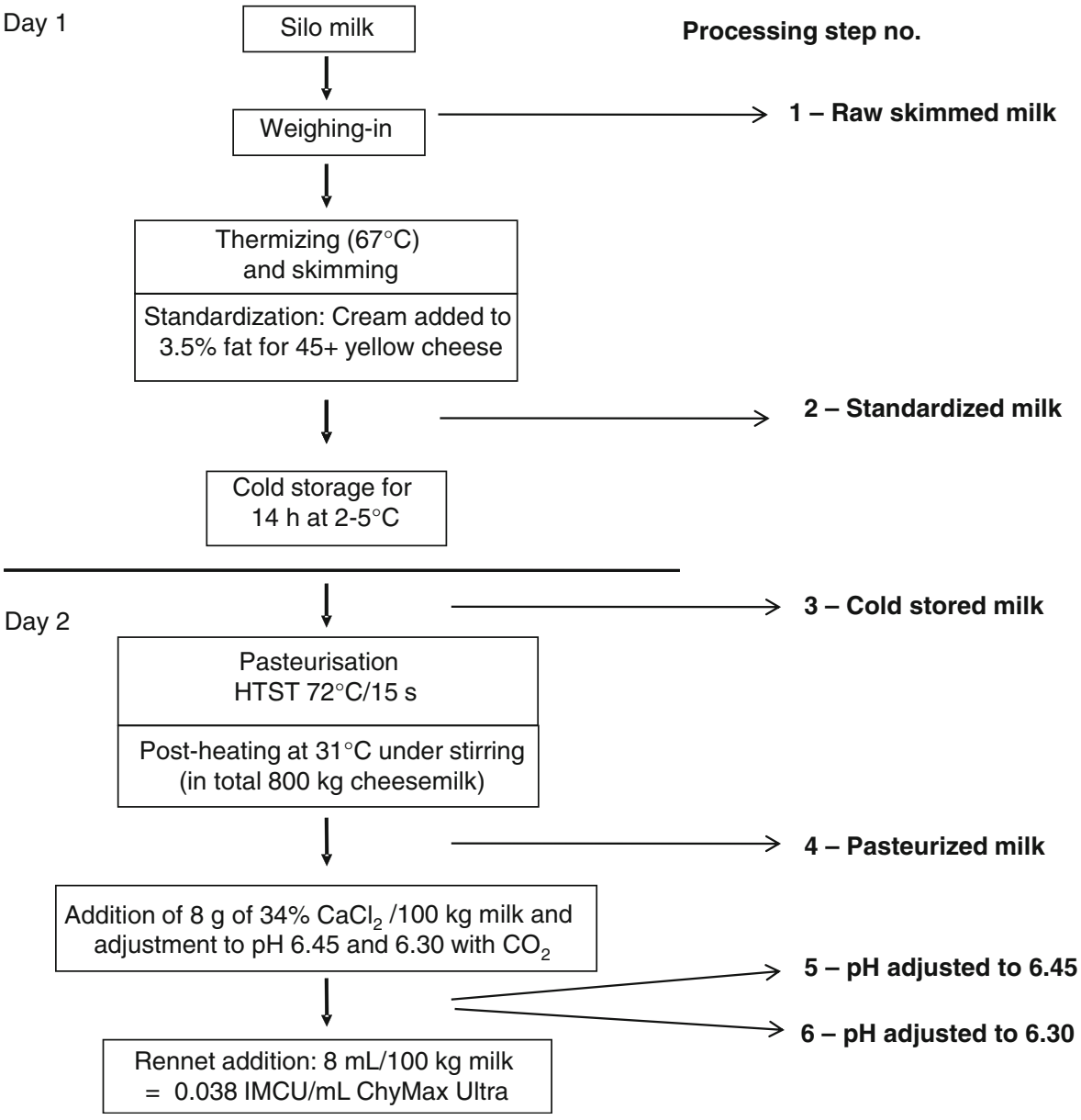

Fig. 1 Cheese processing line and sampling points at the dairy cheese processing plant. HTST high temperature short time

Ultra (Chr. Hansen Laboratories A/S, Denmark). Rheological measurements were performed at $33{ }^{\circ} \mathrm{C}$ for $40 \mathrm{~min}$. RCT (min), G'max $(\mathrm{Pa})$, and CFR $\left[\Delta \mathrm{G}^{\prime} / \Delta \mathrm{t}\right] \mathrm{lin}$ (Pa.min) were selected to describe the coagulation properties of the individual milk samples, essentially as described earlier (Frederiksen et al. 2011b). All rheology analyses were carried out in duplicates.

\subsection{Determination of $\mathrm{Ca}, \mathrm{P}$, and $\mathrm{Mg}$}

In order to evaluate the minerals distribution between the colloidal and soluble phases at different time points $(0,24,48$, and $72 \mathrm{~h}$ of cold storage), the separation into these was performed by ultracentrifugation at $100,000 \times \mathrm{g}$ for $1 \mathrm{~h}$ using a T4-TI-70 rotor in a Beckman-Coulter Optima L-80XP Ultracentrifuge (Beckman Coulter Inc., Brea, CA) (Frederiksen et al. 2011a). To enable comparisons with the rheological measurements, the ultracentrifugation was also performed at $33{ }^{\circ} \mathrm{C}$. 
The determination of contents of $\mathrm{Ca}, \mathrm{P}$, and $\mathrm{Mg}$ in the milk samples from individual cows was performed as described previously (Frederiksen et al. 2011a). Essentially, the content of $\mathrm{P}$ was determined by the vanadomolybdate colorimetric procedure (Stuffins 1967) and $\mathrm{Ca}$ and $\mathrm{Mg}$ contents by atomic absorption spectrophotometry (Atomic Absorption System SP9, Pye Unicam Ltd., Cambridge, UK).

In principle, the supernatant obtained after ultracentrifugation represents the fraction with soluble minerals, and the total contents of $\mathrm{Ca}, \mathrm{Mg}$, and $\mathrm{P}$ were analyzed in skim milk samples and supernatants. From Eq. 1, the colloidal content of minerals was calculated as:

$$
\text { Colloidal }[\mathrm{Ca}, \mathrm{Mg}, \mathrm{P}]=\operatorname{Total}[\mathrm{Ca}, \mathrm{Mg}, \mathrm{P}]-\operatorname{Soluble}[\mathrm{Ca}, \mathrm{Mg}, \mathrm{P}]
$$

All samples were measured in duplicate, and the mineral contents are presented as means of measurements.

\subsection{Casein micelle size distribution by dynamic light scattering}

Casein micelle size was determined by dynamic light scattering (DLS) as described previously (Frederiksen et al. 2011a) at 0 and $72 \mathrm{~h}$ cold-stored skim milk samples from the eight individual cows. The milk samples were diluted 1:100 $(v / v)$ in milk ultrafiltrate (MUF, Arla Dairy Plant, Nr.Vium, Denmark) and analyzed after equilibration to $33{ }^{\circ} \mathrm{C}$ and filtration.

The average micelle diameter and size distribution of casein micelles were determined by DLS on a Malvern Nano S ZEN1600 (Malvern Instruments Ltd., Worcestershire, UK). The particle size measurements were conducted at a fixed angle of $173^{\circ}$ and a wavelength of $633 \mathrm{~nm}$. From the obtained data, the hydrodynamic diameters were calculated by using Stokes-Einsteins equation for spherical particles. Five replicates were performed for each sample, and the hydrodynamic diameters (nm) and the relative particle size distribution by number were determined.

\subsection{Statistical analysis}

The obtained data for the various parameters of coagulation properties, minerals, CMP, and casein micelle size were subjected to statistical analysis by the generalized linear model (GLM) procedure in SAS (SAS, ver 9.3, SAS Institute Inc., Cary, NC).

For the storage experiment, the analysis was done by a two-way model:

$$
Y_{l m n}=a_{l}+b_{m}+a b_{l m}+e_{l m n}
$$

where $a$ is the main effect of storage time $l(0,24,48$, and $72 \mathrm{~h}), b$ is the main effect of coagulation status $m$ (poor, good), $a b$ is the interactive effect between storage time $l$ and coagulation status $m$, and $e$ is the replicate $n(1, . ., x)$.

For the processing experiment, the LS means and standard errors were obtained from a one-way model including processing step. The model (3) of analysis was:

$$
Y_{i k}=a_{i}+e_{i k}
$$

where $a$ is the main effect of processing step $i(1, \ldots, 6)$ and $e$ is the replicate $k(1, . ., x)$. 
The $F$ test was performed to evaluate differences between the means. Differences were regarded significant at $95 \%$ level $(P<0.05)$ as classified by using the Ryan-EinotGabriel-Welsch F multiple range test.

\section{Results}

\subsection{Coagulation properties of poor and good coagulating milk samples}

All rheological parameters were highly significantly different $(P<0.001)$ between the coagulation groups, where the poor coagulating milk had significantly longer RCT, lower CFR, and lower G'max compared with the good coagulating milk. In Fig. 2, the effect of cold storage on the coagulation parameters from the two groups of samples is shown. Generally, cold storage affected RCT significantly, whereas the effect on CFR and G'max was less pronounced. For both milks, a significantly $(P<0.05)$ longer RCT was observed after $24 \mathrm{~h}$ of storage, which was maintained through the $72 \mathrm{~h}$ of storage for the poor coagulating milk. No significant changes were observed for CFR, and poor and good coagulating milk had mean CFR values of 13.5 and 25.1 Pa.min, respectively. Likewise, G'max did not change during cold storage for poor coagulating milk, but after $72 \mathrm{~h}$ of cold storage, G'max was significantly reduced $(P<0.05)$ for the good coagulating milk.

\subsection{Mineral composition and $\mathrm{pH}$ of poor and good coagulating milk samples}

The content and distributions of $\mathrm{Ca}, \mathrm{P}$, and $\mathrm{Mg}$ and the $\mathrm{pH}$ for milk samples classified as good or poor coagulating are presented in Table 1 . The total Ca content of good coagulating milk samples was significantly higher $(P<0.01)$ than the content in poor coagulating samples. This was mainly due to a significantly higher content of colloidal $\mathrm{Ca}(+14 \%)$, whereas the amount of soluble $\mathrm{Ca}$ in serum was only $8 \%$ higher in the good coagulating milk compared with the poor coagulating milk. The contents of $\mathrm{P}$ and $\mathrm{Mg}$ were not significantly different between the groups.

In general, there was around $65 \%$ colloidal Ca compared with around $27 \%$ colloidal $\mathrm{Mg}$ and 50\% colloidal P. This distribution was similar for $\mathrm{Mg}$ and $\mathrm{Ca}$ in good and poor coagulating milk, whereas good coagulating samples had numerically higher colloidal $\mathrm{P}(\sim 15 \%)$ compared with soluble $\mathrm{P}$ though not significant. No differences were found in the $\mathrm{pH}$ of both milks which, on average, was $\mathrm{pH}$ 6.70. The cold storage of the milk for $72 \mathrm{~h}$ did not affect any of these traits significantly (data not shown), neither in good nor poor coagulating milks.

\subsection{Casein micelle diameter of poor and good coagulating milk samples}

There was no significant difference in the hydrodynamic diameter of the casein micelles between the two coagulation groups $(P=0.064)$, even though poor coagulating milk had numerically higher values for micellar diameter (Fig. 3). The smaller micelles in good coagulating milk was reflected in a higher fraction of micelles of smaller sizes, i.e., decreased hydrodynamic diameter compared to poor coagulating milk, which contains a higher fraction of larger micelles (data not shown). 

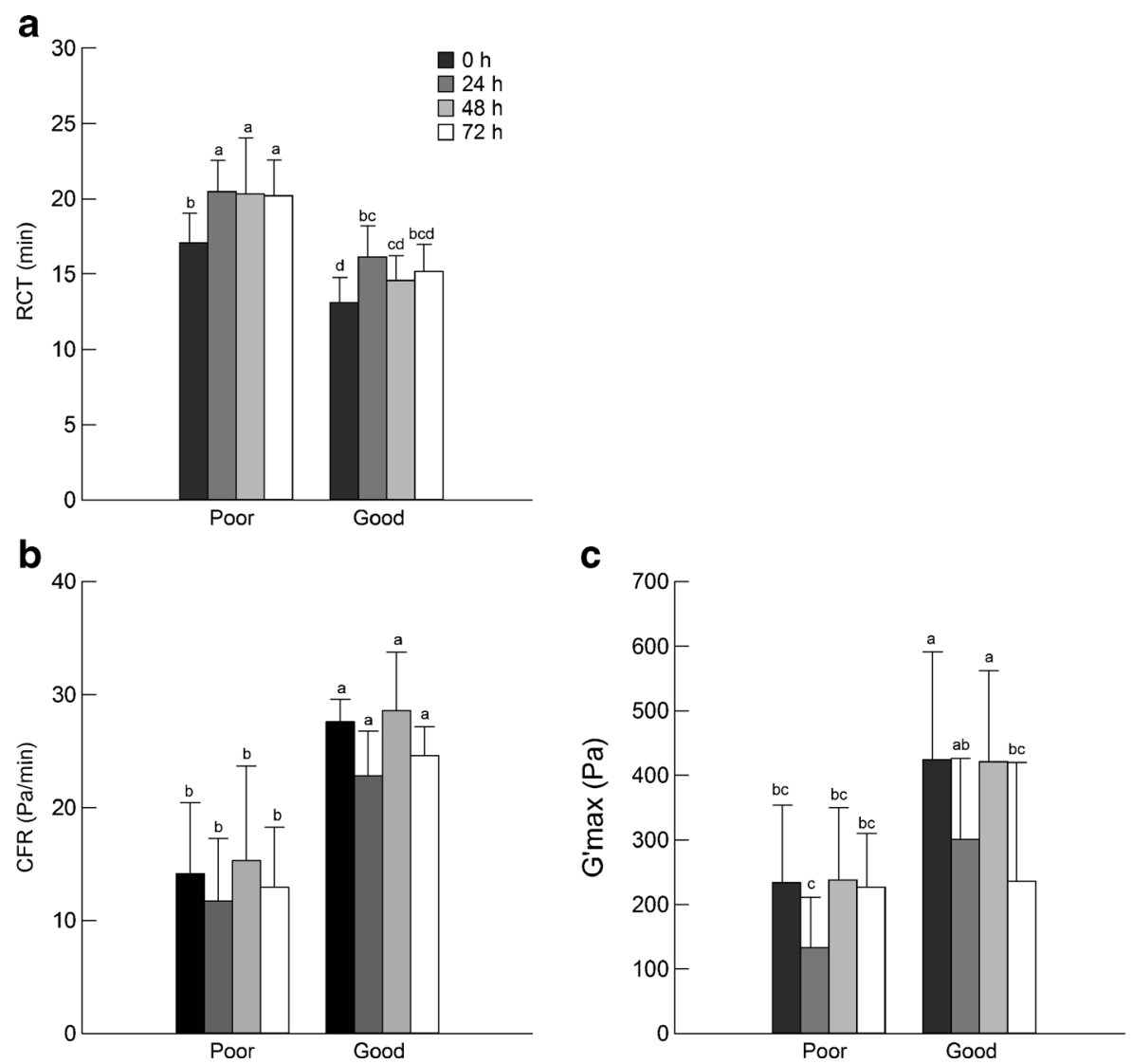

Fig. 2 Rheological parameters of poor and good coagulating milks stored at $4{ }^{\circ} \mathrm{C}$ for $72 \mathrm{~h}$. Rennet coagulation time (a), curding firming rate (b), and curd firmness (c), $P<0.05(n=8)$

In fresh milk, the difference in micelle diameters between the two types was relatively large, i.e., $20 \mathrm{~nm}$. Hence, during storage, the difference diminished as the good coagulating milk micelles increased from a mean diameter of 179 to $199 \mathrm{~nm}$, whereas the micelles in the poor coagulating milk had a mean diameter of $199 \mathrm{~nm}$ prior to storage, which only increased slightly to a mean of $205 \mathrm{~nm}$ (Fig. 3).

\subsection{Coagulation properties of cheesemilk}

The rheological parameters of the six cheesemilk sampled from the dairy plant are given in Table 2. Overall, processing of milk affected all the rheological parameters significantly. Thermization and standardization of the cheesemilk to $3.5 \%$ of fat resulted in a significant decrease in the CFR (Table 2). Neither overnight cold storage of cheesemilk nor high temperature short time (HTST) pasteurization at $72{ }^{\circ} \mathrm{C}$ for $15 \mathrm{~s}$ resulted in any significant changes in the rheological parameters, though RCT was increased after cold storage and restored after pasteurization. The $\mathrm{CaCl}_{2}$ and progressive acidification by $\mathrm{CO}_{2}$ injection to both $\mathrm{pH} 6.45$ and 6.30 
Table 1 Milk mineral composition and $\mathrm{pH}(\mathrm{LS}$ means $\pm \mathrm{SD})$ as a function of milk coagulation ability (poor or good) $(n=8)$

\begin{tabular}{|c|c|c|c|}
\hline & \multicolumn{2}{|c|}{ Coagulation status } & \multirow[t]{2}{*}{$F$ test } \\
\hline & Poor & Good & \\
\hline Total $\mathrm{Ca}(\mathrm{mg} / \mathrm{kg})$ & $1215 \pm 104$ & $1361 \pm 162$ & $* *$ \\
\hline Colloidal Ca (mg/kg) & $780 \pm 82$ & $889 \pm 119$ & $* *$ \\
\hline Soluble Ca (mg/kg) & $435 \pm 54$ & $472 \pm 62$ & $P=0.100$ \\
\hline Total P (mg/kg) & $912 \pm 82$ & $949 \pm 89$ & NS \\
\hline Colloidal P (mg/kg) & $464 \pm 63$ & $506 \pm 73$ & $P=0.112$ \\
\hline Soluble P (mg/kg) & $455 \pm 43$ & $443 \pm 36$ & NS \\
\hline Total Mg (mg/kg) & $119 \pm 15$ & $117 \pm 13$ & NS \\
\hline Colloidal Mg (mg/kg) & $32 \pm 6$ & $31 \pm 6$ & NS \\
\hline Soluble $\mathrm{Mg}(\mathrm{mg} / \mathrm{kg})$ & $87 \pm 10$ & $86 \pm 9$ & NS \\
\hline $\mathrm{pH}$ & $6.72 \pm 0.07$ & $6.69 \pm 0.04$ & NS \\
\hline
\end{tabular}

NS non-significant

$* * P<0.01$

resulted in significantly $(P<0.05)$ shorter RCT and improved the CFR $(P<0.05)$ and G'max $(P<0.05)$, although no significant difference was noticed between $\mathrm{pH}$ 6.45 and $\mathrm{pH} 6.30$.

\section{Discussion}

The results of the present study show that milk of different coagulation classes were impacted differentially during storage at $4{ }^{\circ} \mathrm{C}$. The overall difference in coagulation

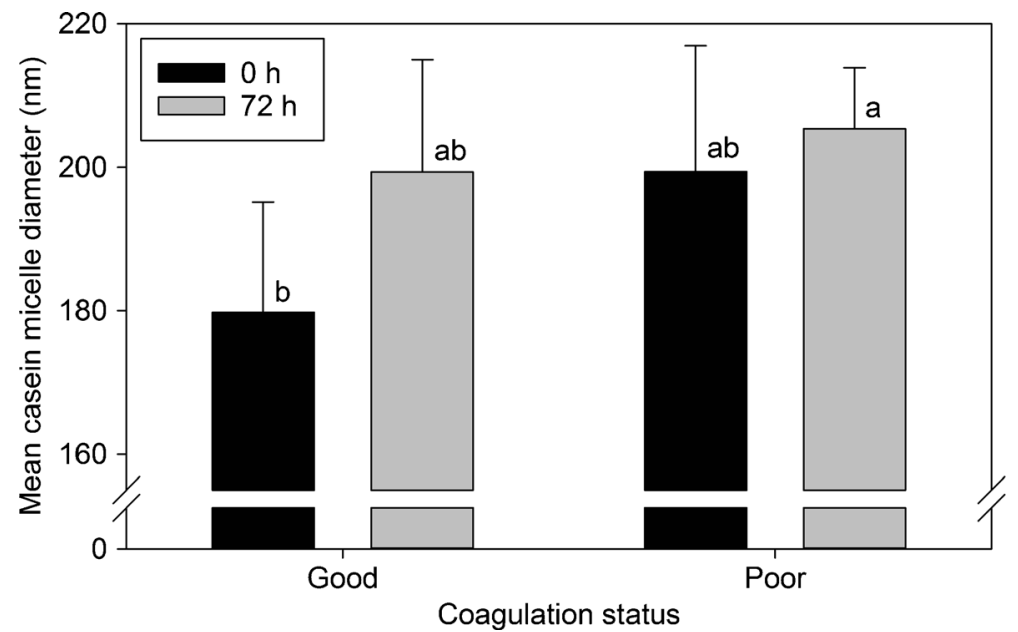

Fig. 3 LS means of casein micelle hydrodynamic diameter $(\mathrm{nm})$ of poor and good coagulating milk samples before $(0 \mathrm{~h})$ and after $(72 \mathrm{~h})$ storage at $4{ }^{\circ} \mathrm{C}(P<0.05)(n=8)$ 
properties between the two classes were partly reflected by differences in $\mathrm{Ca}$ content, especially by substantial higher amounts of total and colloidal $\mathrm{Ca}$ in the milk with good coagulating properties, as well as a numerically higher colloidal P content, which is in line with other studies (Jensen et al. 2012; Malacarne et al. 2014; Gustavsson et al. 2014).

It has been found that good and poor coagulating milks generally present either the same level of CN content (Hallén et al. 2010; Frederiksen et al. 2011b; Bijl et al. 2014) or a lower $\mathrm{CN}$ level in the poorly coagulating (Jensen et al. 2012; Malacarne et al. 2014), depending on study, method of assessment of coagulation class, and number of samples. However, in poorly coagulating milk, a lower amount of Ca might not had been enough to neutralize the negatively charged phosphorylated regions of the $\mathrm{Ca}$ sensitive casein fractions $\left(\alpha_{\mathrm{S}^{-}}, \alpha_{\mathrm{S} 2^{-}}\right.$and $\left.\beta-\mathrm{CN}\right)$ and minimize inter-molecular repulsion (Frederiksen et al. 2011a; Bijl et al. 2013). Therefore, the prevalence of negative charges in micelles with lower amount of both micellar and total $\mathrm{Ca}$ could have prevented the second aggregation phase of rennet-induced coagulation as suggested by Jensen et al. (2012).

The CN micelle hydrodynamic diameters presented in Fig. 3 are similar in magnitude to the values reported by Walsh et al. (1998) and Glantz et al. (2010). It is well reported in the literature that coagulation properties are inversely related to $\mathrm{CN}$ micelle size (Glantz et al. 2011; Bijl et al. 2014; Gustavsson et al. 2014). Milks containing K$\mathrm{CN}$ variant $\mathrm{B}$ presented improved coagulation properties due to smaller $\mathrm{CN}$ micelles and higher concentration of $\mathrm{K}-\mathrm{CN}$ (Walsh et al. 1998; Wedholm et al. 2006). Interestingly, the four poor coagulating cows in the current study presented the $\mathrm{k}-\mathrm{CN}$ haplotype AA (Frederiksen et al. 2011a). The impaired coagulation properties attributed to this haplotype are associated with lower relative concentration of $\mathrm{k}-\mathrm{CN}$ and larger CN micelles (Hallén et al. 2010; Frederiksen et al. 2011a; Jensen et al. 2012). Smaller micelles present larger surface area for reaction, thus forming a more solid-like curd than larger micelles (Niki et al. 1994; Glantz et al. 2010). Our results showed a similar trend, although the difference in micellar size $(\sim 20 \mathrm{~nm})$ was not statistically significant. Indeed, no significant correlation between the different fractions of $\mathrm{Ca}$ and the micellar size over the cold storage was found (data not shown).

Table 2 LS means of rheological parameters of cheesemilk samples as function of processing steps (see Fig. 1) evaluated by Reorox4 (Medirox, Sweden) oscillatory rheological analysis $(n=2)$

\begin{tabular}{|c|c|c|c|c|c|c|c|}
\hline \multirow[b]{3}{*}{$\begin{array}{l}\text { Rheologic } \\
\text { parameter }\end{array}$} & \multicolumn{6}{|c|}{ Processing steps } & \multirow[t]{3}{*}{$F$ test } \\
\hline & \multirow[b]{2}{*}{$\begin{array}{l}1 . \\
\text { Skimming }\end{array}$} & \multirow[b]{2}{*}{$\begin{array}{l}2 . \\
\text { Standardization }\end{array}$} & \multirow[b]{2}{*}{$\begin{array}{l}3 . \\
\text { Cold storage }\end{array}$} & \multirow[b]{2}{*}{$\begin{array}{l}4 . \\
\text { Pasteurization }\end{array}$} & \multicolumn{2}{|c|}{$\mathrm{CaCl}_{2}+\mathrm{CO}_{2}$ injection } & \\
\hline & & & & & $\begin{array}{l}5 . \\
\text { pH } 6.45\end{array}$ & $\begin{array}{l}6 . \\
\text { pH } 6.30\end{array}$ & \\
\hline RCT (min) & $21.2 \pm 2.9^{\mathrm{ab}}$ & $22.2 \pm 0.2^{\mathrm{ab}}$ & $25.2 \pm 7.0^{\mathrm{a}}$ & $18.1 \pm 0.0^{\mathrm{ab}}$ & $12.5 \pm 0.0^{b}$ & $12.7 \pm 0.6^{\mathrm{b}}$ & $*$ \\
\hline CFR (Pa.min) & $13.8 \pm 0.4^{b}$ & $9.6 \pm 0.2^{\mathrm{c}}$ & $11.6 \pm 0.2^{b c}$ & $12.0 \pm 0.7^{\mathrm{bc}}$ & $22.0 \pm 2.5^{\mathrm{a}}$ & $20.3 \pm 0.4^{\mathrm{a}}$ & $* * *$ \\
\hline G'max (Pa) & $229 \pm 161^{b c}$ & $198 \pm 12^{\mathrm{c}}$ & $239 \pm 20^{b c}$ & $209 \pm 30^{\mathrm{c}}$ & $453 \pm 54^{\mathrm{a}}$ & $393 \pm 11^{\mathrm{ab}}$ & $*$ \\
\hline
\end{tabular}

Means with different superscripts within the same line are significantly different $(P<0.05)$

$R C T$ Rennet coagulation time, $C F R$ curd firming rate, G'max maximum gel strength

${ }^{*} P<0.05 ;{ }^{*} P<0.01 ;{ }^{*} * * P 0.001$ (significance of the $F$ test) 
After $72 \mathrm{~h}$ of cold storage, good coagulation milk samples presented a significantly lower G'max of the same magnitude of poor coagulating milk. This decrease seemed to be inversely related to the micellar size, as after $72 \mathrm{~h}$, the mean diameter of casein micelles in good coagulating milk increases and reached the same size as that of poor coagulating milk. An increase in the micellar size at lower temperatures may be ascribed to the dissolution of some $\beta-\mathrm{CN}$ molecules (Walstra et al. 2006). Dissolution of $\beta-\mathrm{CN}$ and its hydrolysis by plasmin was suggested to induce changes in the conformation of casein micelles, which becomes more loosely bound and thus larger in size (Crudden et al. 2005).

In the present study, all samples were adjusted to $\mathrm{pH} 6.5$ in order to provide more optimal conditions for chymosin activity (Home and Banks 2004), although there was no significant difference in $\mathrm{pH}$ between milk samples prior to $\mathrm{pH}$ adjustment. Overall, milk with good coagulating properties had RCT $<15 \mathrm{~min}$, while the average RCT for milk with poor coagulation properties was longer than $19 \mathrm{~min}$. These values are similar to those suggested by Hallén et al. (2010) for normally coagulating ( $<15 \mathrm{~min}$ ) and poorly coagulating $(15-30 \mathrm{~min})$ milk.

The primary stage of chymosin-induced coagulation is the hydrolysis of $\sim 85 \%$ of $\mathrm{K}$ $\mathrm{CN}$ into para- $\mathrm{K}-\mathrm{CN}$ and CMP, followed by initial micelle aggregation (Dalgleish and Corredig 2012). As previously demonstrated by Frederiksen et al. (2011a), the difference in RCT between good and poor coagulating milks is not related to the hydrolysis of $\mathrm{k}-\mathrm{CN}$ by chymosin, as the release of CMP from the micelles was rapidly observed in both milk types. This was also confirmed in the present study, as no significant difference in the CMP content (in mg.mL) after 0.5 min of chymosin addition was observed between both groups (data not shown).

The impact of cold storage in RCT is well documented (Ali et al. 1980; Raynal and Remeuf 2000; Walstra et al. 2006). Longer RCT and thus delayed aggregation may be a consequence of the $\beta-\mathrm{CN}$ migrating from the micellar to the serum phase (and thus also prone to increased level of hydrolysis by plasmin), which further results in a decrease in the hydrophobic interactions and increasing the micelle stability (Dalgleish and Corredig 2012). In the present study, the increase in RCT reached a maximum after 24 h of cold storage. Ali et al. (1980) reported similar trends; however, the maximum elongation in the RCT was reached within $48 \mathrm{~h}$ of storage at $4{ }^{\circ} \mathrm{C}$.

It is likely that changes in the equilibrium between colloidal and soluble $\mathrm{Ca}$ phosphate during cold storage, although slow, affects the equilibrium of casein constituents and their degree of dissociation (Ali et al. 1980; Walstra et al. 2006). The mean CFR for poor coagulating milk was about 2-fold lower than for good coagulating, which is in agreement with the previous findings from the same herd (Frederiksen et al. 2011a). Curd firmness is reported to decrease between 6 and $28 \%$ after 24 to $72 \mathrm{~h}$ of cold storage (Nsofor 1989). Such variation may originate from the different techniques used to monitor the milk coagulation.

Moreover, the acidification to $\mathrm{pH} 6.50$ at $4-7^{\circ} \mathrm{C}$, right before the pre-incubation of the samples at $33{ }^{\circ} \mathrm{C}$ for $30 \mathrm{~min}$, may have contributed to the fluctuation in both CFR and G'max values. Law and Leaver (1998) stressed that acidification of cold milk between $\mathrm{pH} 6.7$ and 5.2 markedly increased the levels of all caseins, $\mathrm{Ca}$ and $\mathrm{P}$ in the serum, although the changes may have been partially reversed by the pre-incubation step (De la Fuente 1998; Gaucheron 2005). In this sense, the impact of the acidification on the milk distribution of casein and minerals of milks with distinct coagulation abilities is still unknown. 
As for milk with distinct coagulation background, technological interventions revealed to have a significant impact on cheesemilk coagulation properties through the processing line. The standardization step significantly decreased the CFR of cheesemilk. As related in the literature, un-homogenized milk fat globules do not play an active role in the gel formation, acting as an inert filler in the curd formation (Home and Banks 2004). The addition of $3.5 \%$ of milk fat to the skim milk seems to slow down the aggregation rate of casein clusters, although not impairing the final strength of the gel. This is likely due to the dilution effect of the protein when adding milk fat, which affects the time to reach the critical phase for continuous connectivity of the major aggregate (Nassar et al. 2001); however, when the final network is formed, its properties are less affected. Milk fat standardization is an important step in cheesemaking to minimize yield losses due to batch to batch and seasonal variations in milk fat content, overcome sensory variation, and create a range of cheeses with different fat content to meet the consumers' demand.

Our results show that overnight cold storage did not have a significant impact on the coagulation properties of cheesemilk. In addition, the presently applied HTST pasteurization process had no significant effect on the coagulation properties, even though the RCT was reduced by approximately $7 \mathrm{~min}$. This is in contrast to previous studies, where pasteurization improved cheesemaking properties by partially reversing the micellar dissociation of $\mathrm{Ca}$, inorganic $\mathrm{P}$, and caseins occurring during cold storage (Ali et al. 1980; Kelly et al. 2008). The substantial improvement in the coagulation properties after the acidification and $\mathrm{CaCl}_{2}$ addition step is in agreement with that stated by numerous authors (Tsioulpas et al. 2007; Hallén et al. 2010). Tsioulpas et al. (2007) reported a stronger correlation of $\mathrm{RCT}$ with $\mathrm{pH}$ rather than $\mathrm{Ca}^{2+}$ concentration, though a minimum amount of $\mathrm{Ca}^{2+}$ ions was imperative to initiate coagulation. In the same study, milk clotting was faster and almost constant between $\mathrm{pH} 6.30$ and 6.55. Among several factors, such improvements can be related to an increase in both chymosin and $\mathrm{Ca}^{2+}$ activity and a reduction in the electrostatic repulsion between the micelles.

The differences in the development of coagulation properties reported in both experiments of the present study could be ascribed to changes affecting the second stage of coagulation. In this way, more profound investigations are needed to characterize the relation between the second stage of chymosin-induced coagulation and changes occurring in the casein micelles during cold storage of individual milks with distinct coagulation abilities and cheesemilk.

\section{Conclusion}

Improved coagulation properties in milk from individual cows were shown to be associated with higher content of total and colloidal $\mathrm{Ca}$ and, to some extent, smaller casein micelles. Cold storage was shown to induce longer RCTs for both milk types after $24 \mathrm{~h}$, whereas gel strength was reduced primarily in the good coagulating milk samples during storage. For cheesemilk, cold storage for up to $14 \mathrm{~h}$ did not impair rheological parameters, although RCT tended to decrease after HTST pasteurization. Further studies are needed to understand how dairy processing steps affect the distribution of casein and minerals between colloidal and serum phases of individual and cheesemilk with different coagulation properties. 
Acknowledgments The authors wish to thank Arla Foods amba, the Danish Cattle Federation, the Ministry of Food, Agriculture and Fisheries, and the Strategic Research Council (Denmark), as well as CAPES (Brazil) for the financial support. Furthermore, the technical support from the staff at the Cattle Research Center (KFC), laboratory technicians Gitte H. Kristiansen and Hanne S. Møller, Aarhus University is gratefully acknowledged.

\section{References}

Ali AE, Andrews AT, Cheeseman GC (1980) Influence of storage of milk on casein distribution between the micellar and soluble phases and its relationship to cheese-making parameters. J Dairy Res 47:371

Bijl E, van Valenberg HJF, Huppertz T, van Hooijdonka CM (2013) Protein, casein, and micellar salts in milk: current content and historical perspectives. J Dairy Sci 96:5455-5464

Bijl E, de Vries R, van Valenberg H, Huppertz T, van Hooijdonk T (2014) Factors influencing casein micelle size in milk of individual cows: genetic variants and glycosylation of K-casein. Int Dairy J 34:135-141

Crabbe MJC (2004) In: Fox PF, McSweeney PLH, Cogan TM, Guinee TP (eds) Cheese: chemistry, physics and microbiology, 3rd edn. Academic, New York

Crudden A, Afoufa-Bastien D, Fox PF, Brisson G, Kelly AL (2005) Effect of hydrolysis of casein by plasmin on the heat stability of milk. Int Dairy J 15:1017-1025

Dalgleish DGD, Corredig M (2012) The structure of the casein micelle of milk and its changes during processing. Annu Rev Food Sci Technol 3:449-467

Dalgleish DG, Horne DS, Law AJR (1989) Size-related differences in bovine casein micelles. Biochim Biophys Acta Gen Subj 991:383-387

De la Fuente M (1998) Changes in the mineral balance of milk submitted to technological treatments. Trends Food Sci Technol 9:281-288

Devold TG, Brovold MJ, Langsrud T, Vegarud GE (2000) Size of native and heated casein micelles, content of protein and minerals in milk from Norwegian Red Cattle-effect of milk protein polymorphism and different feeding regimes. Int Dairy J 10:313-323

Frederiksen PD, Andersen KK, Hammershøj M, Poulsen HD, Sørensen J, Bakman M, Qvist KB, Larsen LB (2011a) Composition and effect of blending of noncoagulating, poorly coagulating, and well-coagulating bovine milk from individual Danish Holstein cows. J Dairy Sci 94:4787-4799

Frederiksen PD, Hammershøj M, Bakman M, Andersen PN, Andersen JB, Qvist KB, Larsen LB (2011b) Variations in coagulation properties of cheese milk from three Danish dairy breeds as determined by a new free oscillation rheometry-based method. Dairy Sci Technol 91:309-321

Gaucheron F (2005) The minerals of milk. Reprod Nutr Dev 45:473-483

Glantz M, Devold TG, Vegarud GE, Lindmark Månsson H, Stålhammar H, Paulsson M (2010) Importance of casein micelle size and milk composition for milk gelation. J Dairy Sci 93:1444-1451

Glantz M, Lindmark Månsson H, Stålhammar H, Paulsson M (2011) Effect of polymorphisms in the leptin, leptin receptor, and acyl-coenzyme A:diacylglycerol acyltransferase 1 (DGAT1) genes and genetic polymorphism of milk proteins on cheese characteristics. J Dairy Sci 94:3295-3304

Gustavsson F, Glantz M, Buitenhuis AJ, Lindmark-Månsson H, Stålhammar H, Andrén A, Paulsson M (2014) Factors influencing chymosin-induced gelation of milk from individual dairy cows: major effects of casein micelle size and calcium. Int Dairy J 39:201-208

Hallén E, Lundén A, Tyrisevä A-M, Westerlind M, Andrén A (2010) Composition of poorly and noncoagulating bovine milk and effect of calcium addition. J Dairy Res 77:398-403

Home DS, Banks JM (2004) In: Fox PF, McSweeney PLH, Cogan TM, Guinee TP (eds) Cheese: chemistry, physics and microbiology, 3rd edn. Academic, New York

Ikonen T, Morri S, Tyrisevä A-M, Ruottinen O, Ojala M (2004) Genetic and phenotypic correlations between milk coagulation properties, milk production traits, somatic cell count, casein content, and $\mathrm{pH}$ of milk. J Dairy Sci 87:458-467

Jensen HB, Poulsen NA, Andersen KK, Hammershøj M, Poulsen HD, Larsen LB (2012) Distinct composition of bovine milk from jersey and holstein-friesian cows with good, poor, or noncoagulation properties as reflected in protein genetic variants and isoforms. J Dairy Sci 95:6905-6917

Jõudu I, Henno M, Kaart T, Püssa T, Kärt O (2008) The effect of milk protein contents on the rennet coagulation properties of milk from individual dairy cows. Int Dairy J 18:964-967

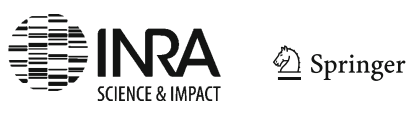


Kelly AL, Huppertz T, Sheehan JJ (2008) Pre-treatment of cheese milk: principles and developments. Dairy Sci Technol 88:549-572

Law AJR, Leaver J (1998) Effects of acidification and storage of milk on dissociation of bovine casein micelles. J Agric Food Chem 46:5008-5016

Lucey JA (2002) Formation and physical properties of milk protein gels. J Dairy Sci 85:281-294

Malacarne M, Franceschi P, Formaggioni P, Sandri S, Mariani P, Summer A (2014) Influence of micellar calcium and phosphorus on rennet coagulation properties of cows milk. J Dairy Res 81:129-136

Mellema M (2002) Effects of structural rearrangements on the rheology of rennet-induced casein particle gels. Adv Colloid Interface Sci 98:25-50

Nassar G, Nongaillard B, Noel Y (2001) Monitoring of milk gelation using a low-frequency ultrasonic technique. J Food Eng 48:351-359

Niki R, Kohyama K, Sano Y, Nishinari K (1994) Rheological study on the rennet-induced gelation of casein micelles with different sizes. Polym Gels Netw 2:105-118

Nsofor LM (1989) Variation in curd firmness of cold-stored raw milk from individual cows. J Food Sci Technol 26:158-160

Poulsen NA, Bertelsen HP, Jensen HB, Gustavsson F, Glantz M, Månsson HL, Andrén A, Paulsson M, Bendixen C, Buitenhuis AJ, Larsen LB (2013) The occurrence of noncoagulating milk and the association of bovine milk coagulation properties with genetic variants of the caseins in 3 Scandinavian dairy breeds. J Dairy Sci 96:4830-4842

Raynal K, Remeuf F (2000) Effect of storage at 4 degrees C on the physicochemical and renneting properties of milk: a comparison of caprine, ovine and bovine milks. J Dairy Res 67:199-207

Stuffins CB (1967) Determination of phosphate and calcium in feeding stuffs. Analyst 92:107-111

Tsioulpas A, Lewis MJ, Grandison AS (2007) Effect of minerals on casein micelle stability of cows' milk. J Dairy Res 74:167-173

Walsh CD, Guinee TP, Reville WD, Harrington D, Murphy JJ, O’Kennedy BT, FitzGerald RJ (1998) Influence of K-casein genetic variant on rennet gel microstructure, cheddar cheesemaking properties and casein micelle size. Int Dairy J 8:707-714

Walstra P, Wouters JTM, Geurts TJ (2006) Dairy science and technology, 2nd edn. CRC Taylor \& Francis Group, Boca Raton

Watkinson P, Coker C, Crawford R, Dodds C, Johnston K, McKenna A, White N (2001) Effect of cheese pH and ripening time on model cheese textural properties and proteolysis. Int Dairy J 11:455-464

Wedholm A, Larsen LB, Lindmark-Månsson H, Karlsson AH, Andrén A (2006) Effect of protein composition on the cheese-making properties of milk from individual dairy cows. J Dairy Sci 89:3296-3305 